\title{
Seleksi Dan Identifikasi Lactobacillus Kandidat Probiotik Penurun Kolesterol Berdasarkan Analisis Sekuen 16s Rna
}

\author{
Selection and Identification of Lactobacillus as Candidates of Cholesterol Lowering Probiotic \\ Using 16S RNA Sequence Analysis
}

Evi Triana dan Novik Nurhidayat

Bidang Mikrobiologi, Pusat Penelitian Biologi, LIPI

Jl. Ir. H. Juanda 18, Bogor 16002. Tlp. (0251)324006, Fax. (0251)325854

E-mail: evitriana03@yahoo.com

\begin{abstract}
High fat and low fiber dietary pattern results in raising of blood cholesterol level over the normal level, namely hypercholesterolemia. Hypercholesterolemia might cause coronary disease and stroke. Blood cholesterol is able to be decreased by probiotic supplement. Lactobacillus is one of the probiotics that were well known and taken advantages. However its role as cholesterol lowering agent was less known. Therefore, screening and identification of Lactobacillus isolates which were candidates of probiotic have been carried out. Isolates Mar 8, Lac 3 and 7 p have been selected as Lactobacillus candidates for cholesterol lowering probiotic. Those isolates met criteria for cholesterol lowering probiotics. Furthermore, they have been conducted to confirm their identity as Lactobacillus. 16S RNA sequences analysis by BLAST analysis against reference strains within DNA Data Bank of Japan (DDBJ) have been carried on. Results showed that sequences of Lactobacillus Mar 8 was 100\% homology with Lactobacillus plantarum, Lac 3 was $100 \%$ homology with Lactobacillus paracasei and 7 p was $99 \%$ homology with Lactobacillus plantarum. It was concluded that the three isolates were selected as candidates for cholesterol lowering probiotics. Both of them, Mar 8 and 7 p, are Lactobacillus plantarum. Another one, Lac 3 is Lactobacillus paracasei.
\end{abstract}

Keywords: probiotics, cholesterol, 16S RNA sequence, Lactobacillus plantarum, Lactobacillus paracasei.

\begin{abstract}
Abstrak
Pola makan yang kaya lemak dan rendah serat dapat menyebabkan kadar kolesterol melebihi batas normal, yang dikenal dengan istilah hiperkolesterolemia. Hiperkolesterolemia dapat menyebabkan penyakit jantung koroner dan stroke. Kadar kolesterol dapat diturunkan dengan pemberian suplemen probiotik. Lactobacillus merupakan salah satu probiotik yang telah banyak dikenal dan dimanfaatkan. Namun demikian, peranannya sebagai penurun kolesterol belum banyak diketahui. Oleh karena itu dilakukan penelitian untuk menseleksi dan mengidentifikasi isolat Lactobacillus yang berpotensi sebagai kandidat probiotik penurun kolesterol. Isolat Mar 8, Lac 3 dan 7 p telah diseleksi sebagai Lactobacillus kandidat probiotik penurun kolesterol. Ketiga isolat tersebut memiliki karakter yang sesuai sebagai probiotik penurun kolesterol, yaitu toleran terhadap pH rendah, serta mampu mengikat kolesterol. Kemudian, terhadap ketiga isolat tersebut dilakukan konfirmasi identitasnya sebagai Lactobacillus dengan melakukan analisis sekuen 16S RNA terhadap galur-galur referensi yang terdapat pada DNA Data Bank of Japan (DDBJ). Hasil analisis menunjukkan bahwa Mar 8 memiliki 100\% sekuen yang homolog dengan Lactobacillus plantarum, Lac 3 memiliki 100\% sekuen yang homolog dengan Lactobacillus paracasei dan 7 p memiliki 99\% sekuen yang homolog dengan Lactobacillus plantarum. Beradasarkan data tersebut disimpulkan bahwa ketiga isolat memenuhi kriteria sebagai probiotik penurun kolesterol. Dari ketiga isolat tersebut, Mar 8 dan 7 p merupakan Lactobacillus plantarum, sedangkan Lac 3 adalah Lactobacillus paracasei.
\end{abstract}

Kata kunci: probiotik, kolesterol, sekuen 16S RNA, Lactobacillus plantarum, Lactobacillus paracasei.

\section{Pendahuluan}

Kolesterol pada dasarnya merupakan lipida. Di dalam tubuh, kolesterol terdapat dalam bentuk lipoprotein. Kolesterol dapat disintesis sendiri secara alami oleh tubuh, terutama hati atau diperoleh dari makanan yang dikonsumsi, antara lain daging, keju, mentega, dan telur ayam. Konsentrasi kolesterol normal dalam darah 160$200 \mathrm{mg} / \mathrm{dl}$ darah. Kolesterol di dalam tubuh berguna untuk berbagai aktivitas fisiologis, antara lain untuk pembentukan hormon-hormon steroid 
seperti hormon kelamin, kortisol dan aldosteron. Kolesterol juga dapat diubah menjadi asam empedu dan dapat diserap oleh hati untuk kemudian disintesis kembali menjadi kolesterol (Anonim, 1999; Seeley, et al., 2000).

Pola makan yang cenderung bergeser menjadi diet yang rendah serat dan kaya lemak dapat menyebabkan kadar kolesterol darah sangat tinggi (hiperkolesterolemia) yang pada gilirannya menyebabkan aterosklerosis. Kondisi ini menjadi momok yang menakutkan karena dapat menyumbat pembuluh darah yang dapat menyebabkan kematian, antara lain sebagai penyebab stroke dan penyakit jantung koroner. Karena itu makanan yang mengandung probiotik, terutama anti kolesterol sangat diperlukan untuk menurunkan kadar kolesterol dalam darah (Anonim, 1999; Siswono, 2002)

Bakteri probiotik merupakan bakteri yang menguntungkan bagi kesehatan inangnya bila dikonsumsi dengan jumlah cukup dalam keadaan hidup, dan tetap hidup saat berada di dalam saluran pencernaan. Bakteri tersebut memiliki kemampuan menekan proporsi bakteri patogen dan meningkatkan komposisi bakteri yang berguna dalam saluran pencernaan. Kriteria probiotik yang digunakan untuk bioterapi penurun kolesterol antara lain toleransi terhadap kondisi asam ( $\mathrm{pH}$ rendah), garam empedu dan mampu mengikat kolesterol. Melalui hasil uji klinis, beberapa jenis bakteri diketahui aman digunakan sebagai probiotik, antara lain Lactobacillus acidophilus, L. casei, L. casei Shirota dan Bifidobacterium (Surono, 2002).

Lactobacillus sebagai probiotik alternatif penurun kolesterol memiliki kemampuan bertahan hidup pada kondisi asam, garam empedu, mampu menghambat bakteri patogen, tahan terhadap antibiotik dan dapat mengikat kolesterol dengan menempel pada epitel dinding saluran pencernaan (Hood \& Zottola, 1998). Umumnya, kolesterol terikat pada membran sel atau dalam bentuk peptidoglikan. Mekanisme pengikatan kolesterol dan dekonyugasi garam empedu merupakan indikasi penurunan kolesterol (Hosono \& Usman, 2000). Selain itu, kemampuan bakteri probiotik Lactobacillus pada makanan fermentasi dalam menurunkan kolesterol darah disebabkan oleh zat anti kolesterol yang dihasilkannya, yang menghambat kerja enzim pembentuk kolesterol (Darnell et al., 1986).
Dari hasil penelitian pada Pusat Penelitian Biologi, LIPI, Kelompok Penelitian Biosistematika dan Genetika Mikroba, Bidang Mikrobiologi, telah diperoleh beberapa isolat Lactobacillus dari berbagai makanan fermentasi dan buah lokal. Terhadap isolat-isolat tersebut akan dilakukan karakterisasi untuk menentukan kandidat probiotik penurun kolesterol. Isolatisolat yang memiliki keunggulan dibandingkan isolat-isolat lain dalam hal kemampuan hidup pada $\mathrm{pH}$ rendah dan pengikatan kolesterol, selanjutnya akan diidentifikasi secara genetik dengan melakukan analisis sekuen 16S RNA.

\section{Bahan Dan Metode}

\section{Isolat Lactobacillus}

Lactobacillus yang diuji, diisolasi dari markisa, dadih dan acar. Media isolasi yang digunakan adalah GYP (Glucose-Yeast extract-Peptone) agar, dengan komposisi sebagai berikut: $10 \mathrm{~g}$ glukosa, $10 \mathrm{~g}$ yeast ekstract, $5 \mathrm{~g}$ pepton, $2 \mathrm{~g}$ beef extract, $1,4 \mathrm{~g} \mathrm{Na}$-asetat. $3 \mathrm{H}_{2} \mathrm{O}, 5 \mathrm{ml}$ salt solution $\left(0,1 \mathrm{~g} \mathrm{MgSO}{ }_{4} .7 \mathrm{H}_{2} \mathrm{O} ; 0,1 \mathrm{~g} \mathrm{MnSO}_{4} .4 \mathrm{H}_{2} \mathrm{O} ; 0,1 \mathrm{~g}\right.$ $\mathrm{FeSO}_{4} .7 \mathrm{H}_{2} \mathrm{O} ; 0,1 \mathrm{~g} \mathrm{NaCl} ; 50 \mathrm{ml}$ akuades), $0,5 \mathrm{~g}$ tween $80,20 \mathrm{~g}$ agar, 1 liter air. Setelah disterilisasi, ditambahkan $0,075 \mathrm{mg} \mathrm{CaCO}_{3} / \mathrm{ml}$ media.

\section{Seleksi Probiotik Lactobacillus}

Seleksi terhadap Lactobacillus untuk menjadi kandidat probiotik penurun kolesterol dilakukan terhadap isolat-isolat yang memiliki keunggulan karakter-karakter berikut:

a. Toleransi terhadap $\mathrm{pH}$ rendah

Uji toleransi terhadap $\mathrm{pH}$ rendah dilakukan dengan cara mengamati pertumbuhan isolat pada media MRS broth yang $\mathrm{pH}$-nya diatur hingga mencapai 2,5. Kekeruhan media diukur menggunakan spektrofotometer pada panjang gelombang 600, setelah diinkubasi selama 0, 24, 48 dan 72 jam. Pengamatan dilakukan sebanyak tiga ulangan.

b. Daya ikat kolesterol

Daya ikat kolesterol oleh isolat-isolat Lactobacillus diukur menggunakan metoda Human Cholesterol Liquicolor. Pengukuran Optical Density (OD) dilakukan menggunakan spektroskopi pada panjang gelombang 500 . 


\section{Identifikasi Lactobacillus}

a. Ekstraksi DNA

DNA diekstraksi menggunakan metoda standar Sambrook ( 1989).

b. Amplifikasi DNA

DNA diamplifikasi dengan cara PCR dengan TaKaRa Ex Taq (1.000U), primer universal 9F (5'-GAGTTTGATCCTGGCTCAG-3') dan 1541R (5'-AAGGAGGTGATCCAGCC3'). Total campuran PCR terdiri dari $1 \mu 1$ masing-masing primer $(20 \mathrm{mM}), 1 \mu \mathrm{l}$ DNA template, $4 \mu \mathrm{l}$ dNTP, $5 \mu \mathrm{l}$ 10x bufer PCR, $0.25 \mu \mathrm{l}$ Ex Taq polymerase, dan akuades hingga mencapai volume total $50 \mu \mathrm{l}$. Kondisi siklus termal adalah sebagai berikut: denaturasi DNA pada suhu $95^{\circ} \mathrm{C}$ selama 30 detik; 30 putaran yang terdiri dari primer annealing pada suhu $55^{\circ} \mathrm{C}$ selama 15 detik dan primer extension pada suhu $72^{\circ} \mathrm{C}$ selama 1 menit. Setelah selesai 30 putaran, suhu $72^{\circ} \mathrm{C}$ dipertahankan selama 5 menit untuk penyempurnaan amplifikasi dan didinginkan hingga mencapai $4^{\circ} \mathrm{C}$ selama beberapa saat (hold). DNA yang telah diamplifikasi, dipurifikasi menggunakan QIAquick PCR Purification Kit (QIAGEN) menurut prosedur yang dikeluarkan oleh pabrik/pembuat.

c. Sekuensing gen $16 \mathrm{~S}$ RNA

DNA yang telah murni disekuen menggunakan Big Dye Terminator V3.1 Cycle Sequencing Kit, GeneAmp PCR System 9700 (Applied Biosystem) menurut prosedur yang dikeluarkan oleh pabrik/pembuat. Pasangan primer yang digunakan adalah 9F (5'AGTTTGATCCTGGCTCAG-3'), 785F (5'GATTAGATACCCTGGTAGTC-3'), 802R (5'-TACCAGGGTATCTAATCC-3'), 1541R (5'-AAGGAGGTGATCCAGCC-3'). Siklus termal berlangsung pada kondisi sebagai berikut: Pre-denaturasi pada suhu $96^{\circ} \mathrm{C}$ selama 1.5 menit; 25 Putaran thermal cycling yang terdiri dari: denaturasi pada suhu $96^{\circ} \mathrm{C}$ selama 10 detik, primer annealing pada suhu $50^{\circ} \mathrm{C}$ selama 5 detik, primer extension pada suhu $60^{\circ} \mathrm{C}$ selama 4 menit dan pendinginan/cooling hingga mencapai suhu $4^{\circ} \mathrm{C}$ selama beberapa saat (hold). Sekuen $16 \mathrm{~S}$ RNA yang diperoleh, dimurnikan menggunakan CleanSeq Kit (Agencourt) menurut prosedur yang dikeluarkan oleh pabrik/pembuat, selanjutnya dianalisis menggunakan ABI Prism 3100 Sekuenser.

d. Analisis sekuen

Sekuen 16S RNA di-assamble menggunakan perangkat lunak ATGC Sequencing Analyses versi 4.0 (ABI Prism) dan keempat sekuen dari masing-masing primer disejajarkan bersama-sama menggunakan perangkat lunak ARB kemudian nukleotida-nukleotida penyusunnya dikoreksi secara langsung. Data sekuen dari tiap isolat Lactobacillus dirujuk ke DNA Data Bank of Japan (DDBJ) untuk diketahui galur kerabat terdekatnya menggunakan analisis Blast.

\section{Hasil Dan Pembahasan}

Pada Tabel 1, terlihat bahwa kesembilan isolat yang diuji mampu bertahan hidup pada kondisi asam $(\mathrm{pH} 2,5)$ hingga hari ke-3, terlihat dari kekeruhan medium yang cenderung meningkat, yang menunjukkan adanya pertumbuhan. Hal tersebut sesuai dengan penelitian terdahulu yang menyatakan bahwa sifat Lactobacillus antara lain adalah tahan terhadap asam. Dalam keadaan asam, Lactobacillus mampu mempertahankan kadar keasaman sitoplasmanya sehingga protein dan enzim yang berada di dalam sel tetap dapat bekerja secara optimal. Karakter inilah yang menyebabkan Lactobacillus sangat ideal sebagai probiotik saluran pencernaan, karena salah satu persyaratan probiotik yang baik yaitu tahan terhadap keasaman hingga $\mathrm{pH}$ 2. Hal ini diperlukan karena mikroba probiotik harus dapat tetap hidup hingga disaluran pencernaan. Isolat Lac 3 menunjukkan toleransi tertinggi terhadap kondisi asam dibanding isolat lainnya.

Selain toleransi terhadap kondisi asam yang tinggi, kemampuan mengikat kolesterol mutlak dibutuhkan oleh kandidat probiotik penurun kolesterol (Surono, 2002). Pada Tabel 2 terlihat bahwa dari sembilan isolat Lactobacillus yang diuji, tiga isolat, yaitu isolat Mar 8, $7 \mathrm{p}$ dan Lac 3 mempunyai kemampuan mengikat kolesterol yang lebih tinggi dibanding isolateisolat lain. Berdasarkan Human Cholesterol Liquicolor Test Kit yang digunakan, Isolat Mar 8 memperlihatkan konsentrasi kolesterol terikat 4,167 mmol/l; 7 p 4,375 mmol/l; sedangkan Lac $3 ; 3,743 \mathrm{mmol} / \mathrm{l}$. 
Tabel 1. Pertumbuhan Lactobacillus pada $\mathrm{pH} 2.5$.

\begin{tabular}{ccccc}
\hline \hline \multirow{2}{*}{ Kode Isolat } & \multicolumn{4}{c}{ Absorbasi Kekeruhan OD $\boldsymbol{\lambda}=\mathbf{6 0 0}($ hari ke - ) } \\
& $\mathbf{0}$ & $\mathbf{1}$ & $\mathbf{2}$ & $\mathbf{3}$ \\
\hline \hline 5H6 & 0.964 & 1.007 & 1.009 & 1.021 \\
Mar 4 & 0.953 & 1.005 & 1.020 & 1.028 \\
Mar 8 & 1.039 & 1.083 & 1.100 & 1.112 \\
L1 & 0.797 & 0.851 & 0.860 & 0.866 \\
L23 & 0.736 & 0.779 & 0.786 & 0.800 \\
5p & 0.945 & 1.019 & 1.028 & 1.036 \\
7p & 0.830 & 0.884 & 0.965 & 0.905 \\
Lac 2 & 0.923 & 0.992 & 0.987 & 1.017 \\
Lac 3 & 1.245 & 1.315 & 1.337 & 1.327 \\
\hline \hline
\end{tabular}

Fermentasi yang dilakukan oleh Lactobacillus menyebabkan turunnya derajat keasaman, yang mengakibatkan terjadinya pemisahan partikel LDL (Low Density Lipoprotein) yang secara awam disebut kolesterol jahat, dari reseptornya. Kemudian LDL diuraikan menjadi asam amino, kolesterol dan asam lemak bebas. Selanjutnya kolesterol diikat oleh Lactobacillus dalam bentuk peptidoglikan. Walaupun isolat Lac 3 dapat bertahan pada kondisi asam lebih baik, namun kemampuan mengikat kolesterol lebih rendah daripada isolat Mar 8 dan 7 p.

Tabel 2. Daya ikat kolesterol oleh isolat-isolat Lactobacillus

\begin{tabular}{ccc}
\hline \hline Kode Isolat & Absorbansi OD $\boldsymbol{\lambda}=\mathbf{5 0 0}$ & Konsentrasi Kolesterol Terikat $(\mathbf{m m o l} / \mathbf{l})$ \\
\hline \hline Kontrol & 0.031 & 0 \\
Mar 4 & 0.023 & 1.667 \\
Mar 8 & 0.011 & 4.167 \\
$5 \mathrm{p}$ & 0.026 & 1.042 \\
$7 \mathrm{p}$ & 0.010 & 4.375 \\
L1 & 0.017 & 2.917 \\
L23 & 0.013 & 3.3750 \\
Lac 2 & 0.009 & 0 \\
Lac 3 & 0.013 & 3.745 \\
\hline \hline
\end{tabular}

Dalam saluran pencernaan, asam empedu merupakan rintangan alami yang dapat menghambat semua jenis mikroba yang masuk bersama makanan, sehingga berpengaruh terhadap viabilitas probiotik yang sengaja dikonsumsi.

Sebagai kandidat probiotik penurun kolesterol, toleransi yang tinggi terhadap garam empedu adalah syarat penting untuk dapat bertahan hidup dalam saluran pencernaan. Penelitian Gohran pada tahun 1994 memperkuat pendapat yang menyatakan bahwa salah satu syarat probiotik untuk dapat menurunkan kolesterol adalah kemampuan hidup pada media pertumbuhan yang mengandung natrium taurokolat. Natrium-taurokolat merupakan asam empedu yang terkonyugasi dengan taurine yang terdapat dalam cairan empedu yang bersifat alkali (alkaline hepatic bile).
Ketiga isolat yang memiliki keunggulan dalam hal toleransi terhadap $\mathrm{pH}$ rendah dan kemampuan mengikat kolesterol, yaitu Lac 3, Mar 8 dan $7 \mathrm{p}$, terbukti mampu tumbuh pada medium yang mengandung natrium taurokolat. Isolat Mar 8 menunjukkan kemampuan hidup yang lebih baik dibandingkan isolat Lac 3 dan 7 p (Napitupulu et al., 2003). Toleransi ketiga isolat tersebut dapat menjadi indikasi bahwa ketiga isolat mampu melakukan dekonyugasi garam empedu, yaitu pemisahan ikatan ester penyusun natrium-taurokolat. Kemampuan tersebut disebabkan oleh aktivitas enzim Bile Salt Hidrolase (BSH). BSH bereaksi dengan natrium taurokolat membentuk asam kolat yang menjadi faktor pereduksi kolesterol (Surono, 2002).

Selain asam kolat, asam folat bersama beberapa asam organik lain terbukti dihasilkan oleh isolat Lac 3, Mar 8 dan 7 p berdasarkan 
analisis HPLC (High Performance Liquid Chromatography) dalam penelitian yang dilakukan oleh Napitupulu et al., (2003). Asam organik tersebut adalah: glukonat, glukoronat, galakturonat, fenolat, laktat, propionat, asetat, dan tanat. Secara umum, isolat $7 \mathrm{p}$ menghasilkan asam-asam organik lebih tinggi dibandingkan dengan isolat Mar 8 dan Lac 3.

Ketiga isolat dapat bertahan hidup dan tetap melakukan metabolisme dalam lingkungan yang mengandung konsentrasi garam empedu tinggi, karena mampu memanfaatkan garam empedu sebagai sumber makanan. Hal tersebut menyebabkan terjadinya perubahan struktur kimia asam empedu. Asam empedu yang telah berubah strukturnya karena aktivitas mikroba tersebut tidak dapat diserap kembali oleh hati (Seeley et al., 2000), sehingga tidak dapat lagi digunakan oleh hati untuk sintesis kolesterol. Dengan cara ini, mikroba yang mampu menggunakan asam empedu dapat dimanfaatkan sebagai salah satu alternatif untuk menurunkan kadar kolesterol.

Berdasarkan data-data tersebut, tiga isolat terpilih menjadi kandidat probiotik penurun kolesterol. Ketiga isolat tersebut adalah Mar 8, Lac 3 dan 7 p. Berdasarkan karakter yang secara rutin diamati saat isolasi Lactobacillus dari berbagai sampel, diyakini bahwa ketiga isolat tersebut adalah Lactobacillus. Karakter tersebut antara lain sel berbentuk batang, gram positif, non-motil, tidak berspora, dan katalase negatif. Karakter-karakter tersebut adalah karakter yang umum dimiliki oleh Lactobacillus.

Melalui hasil uji klinis, beberapa Lactobacillus yang umum digunakan sebagai probiotik adalah Lactobacillus acidophilus, Lactobacillus casei dan Lactobacillus casei Shirota. Bakteri-bakteri probiotik tersebut aman dikonsumsi (Surono, 2002). Karena itu isolat Lac 3, Mar 8 dan 7 p selanjutnya diidentifikasi secara genetis, untuk mengetahui apakah ketiganya merupakan jenis bakteri yang aman dikonsumsi.

Berdasarkan hasil analisis secara genetis, yaitu analisis sekuen 16S RNA, diketahui bahwa isolat Lac 3 tidak memiliki satu pun basa yang berbeda dengan dengan Lactobacillus paracasei subspecies paracasei strain A221, yang berarti memiliki $100 \%$ sekuen yang homolog dengan $L$. paracasei subspecies paracasei strain A221. Demikian pula dengan isolat Mar 8 yang memiliki 100\% sekuen yang homolog dengan Lactobacillus plantarum strain WCFS1. Sedangkan isolat $7 \mathrm{p}$ memiliki 99\% sekuen yang homolog dengan Lactobacillus plantarum strain HOKKAIDO, dimana hanya 1 basa yang berbeda dengan $L$. plantarum strain HOKKAIDO.

Dari data tersebut, terlihat bahwa dua isolat, yaitu Mar 8 dan $7 \mathrm{p}$ adalah Lactobacillus plantarum. Sementara sampai saat ini, Lactobacillus plantarum masih jarang digunakan sebagai probiotik. Karena itu perlu dilakukan penelitian untuk menentukan apakah Lactobacillus plantarum layak digunakan sebagai probiotik saluran pencernaan, khususnya sebagai agen penurun kolesterol.

\section{Kesimpulan}

Tiga isolat Lactobacillus Lac 3, Mar 8 dan 7 p dapat dijadikan kandidat probiotik penurun kolesterol, karena ketiga isolat tersebut tahan hidup pada kondisi asam ( $\mathrm{pH} 2,5)$ dan sanggup mengikat kolesterol secara berturut-turut sebesar $3,743 \mathrm{mmol} / \mathrm{l}, 4,167 \mathrm{mmol} / \mathrm{l}$, dan 4,375 $\mathrm{mmol} / \mathrm{l}$. Berdasarkan hasil analisis genetik, telah diidentifikasi bahwa isolat Lac 3 adalah Lactobacillus paracasei, sedangkan Mar 8 dan $7 \mathrm{p}$ adalah Lactobacillus plantarum.

\section{Daftar Pustaka}

Anonim. 1999. Penyakit Jantung dan Stroke. http://www.sarikata.com/index.php?fuseaction=home. baca.id=810. 6 September 2004 .

Darnell, J., Lodish, H. and Baltimore, D. 1986. Molecular Cell Biology. Scientific American Books, Inc. New York.

Gohran, M. 1994. Lactobacillus with The Ability of Colonization and Establishing in The Intestinal Tract. Japan Patent: 6-50 (625).

Hood, S.K. and Zottola, E.A. 1998. Effect of Low $\mathrm{pH}$ and The Ability of Lactobacillus acidophilus to Survey and Adherence to Human Intestinal Cells. J. Food Sci., 53:1514-1516.

Hosono, A. and Usman. 2000. Bile Tolerance, Taurocholate Deconjugation, and Binding Cholesterol by Lactobacillus gasseri Strain. J. Diary Sci. 82:243-248

Napitupulu, R.N.R., Yulinery, T., Hardiningsih, R., Kasim, E. dan Nurhidayat, N. 2003. Daya Ikat Kolesterol dan Produksi Asam Organik Isolat Lactobacillus Terseleksi untuk Penurun Kolesterol. Prosiding Pertemuan Ilmiah Tahunan Perhimpunan Mikrobiologi Indonesia. Bandung, 29-30 Agustus 2003. 
Sambrook, J.E., Fritsch, F. and Maniatis, T. 1989. Molecular Cloning: A Laboratory Manual. Cold Spring Harbor. New York.

Seeley, R.R., Trent, D.S., and Philip, T. 2000. Anatomy and Physiology. $7^{\text {th }}$ ed. Mc.Graw Hill Comp. New York.

Siswono. 2002. 'Fast Food' Harus Dikonsumsi Terencana. http://www.gizi.net/cgi- bin/berita/fullnews.cgi?newsid1036726543,54127. 5 Mei 2004.

Surono, I. 2002. Efek Probiotik Minuman Fermentasi Dadih dari Sumatra Barat. Makalah Symposium on Biotechnology of Probiotic for Human Health. BPPT. Jakarta. 